\title{
Tabus sexuais entre professores e alunos
}

Antônio Zuin*

Resumo: $O$ poder da sexualidade nas relaçôes entre professores e alunos é táo intenso quanto o esforço feito pelos agentes educacionais em negá-lo. O termo tabu representa a exata designação do que tal terminologia suscita: algo misterioso e, principalmente, proibido. De fato, a questão sexual entre professores e alunos concerne a uma esfera tão proibitiva que sequer é mencionada, haja vista a escassez de pesquisas que versam a esse respeito. Daí o objetivo deste artigo, ou seja, analisar a ambivalência dos sentimentos de amor e de ódio que se objetivam na sexualidade existente entre professores e alunos.

Palavras-chave: indústria cultural; tabus sexuais; teoria crítica; Sócrates; Theodor Adorno.

\section{Sexual taboos among teachers and students}

Abstract: The power of sexuality in teacher-student relationships is as intense as the effort made by educational institutions to deny it. The term "taboo" represents the exact designation of what such terminology means: something mysterious and mainly forbidden. In fact, the sexual issue among teachers and students concerns such a forbidding sphere that it is hardly mentioned, which explains the little research that has been carried out in this field. Thus, this paper is aimed at analyzing the ambivalence of feelings of love and hate found in the teacherstudent sexuality.

Key words: culture industry; sexual taboos; critical theory; Socrates; Theodor Adorno.

\section{Introdução}

A força da sexualidade nas relações estabelecidas entre alunos e professores é tão intensa quanto o esforço feito pelos agentes educacionais em negá-la. As vozes oficiais das instituiçôes escolares empenham-se na vã tentativa de fazer com que quaisquer indícios de manifestaçôes da sexualidade entre professores e alunos sejam imediatamente reprimidos. Não por acaso, causam espanto e perplexidade os casos de envolvimento sexual entre alunos e professores, os

* Professor-Associado do Departamento de Educação e do Programa de Pós-Graduação da Universidade Federal de São Carlos (UFSCar), SP. Brasil. Pesquisador CNPq ID e Assessor Fapesp.dazu@ufscar.br 
quais frequientemente são estampados nas manchetes e nos textos de jornais, de revistas e de telejornais.

Talvez o termo tabu represente a designação exata daquilo que tal temática suscita: trata-se de algo misterioso e, principalmente, proibido. De todo modo, não pode haver qualquer tipo de violação da regra tácita de que professores e alunos, durante situações ocorridas nas salas de aula, devam comprometer-se com a concentração apenas em dados objetivos. Se os elementos da dimensão subjetiva se revelaram determinantes para concretização do processo de ensino-aprendizagem do aluno, a ponto de serem caracterizados pela sociologia da educação como componentes do chamado currículo oculto, a questão sexual refere-se a uma esfera tão proibitiva que sequer é mencionada, haja vista a escassa quantidade de pesquisas que versam a esse respeito. Qualquer sinal de manifestação da sexualidade torna-se passível de ser reprovado, a ponto de a sentença condenatória da própria sociedade ser aplicada, em algumas situaçôes, de forma indelével. O julgamento precipitado, que foi nutrido pelas estampas sensacionalistas e espetaculares da imprensa brasileira em 1994, condenou os donos e um auxiliar da Escola Base, da cidade de São Paulo, como monstros sexuais, justamente porque seus comportamentos foram associados ao exercício da sexualidade monstruosa. Evidentemente, os abusos sexuais cometidos em crianças devem ser punidos com todo o rigor da lei, mas, nesse caso, a menção da questão sexual foi também decisiva para a vitória do pensamento estereotipado que rotulou tais pessoas e que contribuiu para a produção de prejuízos morais dificilmente reversíveis, por mais que se reconheçam, judicialmente, os danos provocados pelas interpretaçôes açodadas. ${ }^{1}$

A simples menção da sexualidade entre professores e alunos adquire uma conotação de incesto que precisa ser sobejamente negada e condenada. Se esse raciocínio estiver correto, quais seriam os fatores determinantes para a identificação do componente proibitivo quando se estuda a questão da sexualidade entre mestres e alunos? Que tipo de processo sociabilizador se nota entre professores e alunos que converte a sexualidade a uma condição de tabu?

São questôes como estas que teimam em permanecer atuantes nas relaçôes do cotidiano escolar, por mais que se procure afastá-las. A esfinge sexual revitaliza sua ameaça do "decifra-me ou te devoro", pois, mesmo que seja continuamente

1. Os donos da Escola Base, Maria Aparecida Shimada e seu marido Icushiro Shimada, e mais o colaborador Maurício de Alvarenga, ganharam uma indenização de cem salários mínimos por danos morais a ser paga pelo governo de São Paulo. Eles recorreram à Justiça depois que a polícia os acusou injustamente, em 1994, de promover orgias com menores na escola infantil que mantinham até então. Algumas das manchetes dos jornais e revistas naquela ocasiāo foram: "Perua escolar carregava crianças para orgia" (jornal Folha da Tarde). "Escola de horrores" (revista Veja). Disponível em http://umw. Igutenberg.org/esbase.html, 2007. 
condenada, provoca efeitos que não podem ser simplesmente amainados, caso não sejam assumidos como de fato deveriam ser.

A caracterização das relaçōes sexuais entre professores e alunos de ambos os gêneros sexuais como incestuosa remete o pensamento para a importância da investigação do sexo e, principalmente, do amor e do ódio que se pode observar nas relaçôes estabelecidas entre tais agentes educacionais. Daí o objetivo deste artigo, ou seja, analisar a ambivalência de tais sentimentos que se objetivam na sexualidade existente entre professores e alunos.

\section{Eros como impulso cultural}

A expressão: amor platônico caracteriza um tipo de amor tão inalcançável quanto ardentemente desejado. Os amores trágicos e impossíveis foram, e ainda são, temas fartamente utilizados nas produçôes artísticas, dentre os quais se destacam os indefectíveis Romeu e Julieta, de Shakespeare, e Os sofrimentos do jovem Wether, de Goethe. Mas talvez o amor impossível jamais tenha adquirido maior expressão do que na obra-prima do escultor renascentista Gian Lorenzo Bernini intitulada Apolo e Dafne. Trata-se de uma escultura em tamanho natural, que pode ser vista no Museu da Galleria Borghese, em Roma, alusiva ao mito de Apolo e Dafne, o qual foi difundido para a cultura ocidental por meio dos poemas das Metamorfoses, de Ovídio. Dafne era uma ninfa seguidora da deusa Diana e filha do rio Peneo. Numa certa ocasião, inconformado em ser derrotado por Apolo numa disputa de arco e flecha, Cupido (Eros, o deus do amor) vinga-se da seguinte forma: ele flecha Apolo com a seta do amor e atinge Dafne com uma seta de chumbo, o que lhe causa imensa repulsa a Apolo. O deus solar não se conforma com a recusa da ninfa e a persegue por todos confins do mundo. No momento em que consegue alcançá-la para possuí-la, Dafne roga a seu pai e é imediatamente transformada numa árvore de louros, a qual, não por acaso, não produz frutos. A expressão de decepção e perplexidade de Apolo, diante da transformação de Dafne, foi magistralmente imortalizada por Bernini. É interessante observar que este mito foi reapropriado, na Idade Média, pelo clero, que louvou a imagem de Dafne como símbolo da virtude, pois se tratava de um amor casto e extremamente ilustrativo da metamorfose da matéria em algo de natureza espiritual (Coliva, 1998, p.30).

De certa forma, os finais trágicos de tais obras alimentaram o prazer e a crença de que há um amor tão elevado que transcende o gozo material e se metamorfoseia em amor "puro". Justamente porque o amor "puro" se isenta da concupiscência sexual, seu portador transfere, por assim dizer, praticamente toda sua libido para a idealização de um tipo de modelo que passa ser a sua referência. E quanto mais distante, mais "saboroso" se torna esse amor. Mas 
será que tal expressão faz jus às idéias de Platão e de seu mestre Sócrates? Na leitura do já clássico texto: Paidéia: a formação do homem grego, Jaeger destaca a relevância, em Platão, dos elementos instintivos para o processo de estruturação do conceito do Belo:

Na sua teoria do cros lança uma audaciosa ponte sobre o abismo que separa o apolíneo do dionisíaco. Ele (Platão,-A.Z) julga que, sem o impulso e o entusiasmo inesgotáveis e incessantemente renovados das forças irracionais do Homem, jamais será possível atingir o cume daquela transfiguração suprema que atinge o espírito, quando este contempla a idéia do Belo. A união do Eros e da Paidéia, eis a idéia central do Banquete. (Jaeger, 1995, p.724).

Da comunhão entre Eros e a Paidéia infere-se ser justamente a força de Eros a que impulsiona os avatares do processo formativo do espírito. Ou seja, a metamorfose suprema que o espírito atinge quando contempla os significados das essências dos conceitos e, por que não dizer, das entidades Justiça, Virtude, Beleza e Bondade, não seria crível não fosse a potência do motor que movimenta e impulsiona o próprio espírito: o amor. Ademais, assim como o filósofo-educador anseia obter um conhecimento mais aprimorado dos significados dos conceitos e se situa na mediania entre a sapiência e a ignorância, também Eros carece de ser belo e bom, embora não desista de lutar para sê-lo (Platão, 1991, p. 32-33).

Ora, se Eros se ressente de algo que não possui e se sua natureza é identificada por tal carência, ele pode direcionar suas forças tanto para a realização de desejos exclusivamente relativos ao regozijo material quanto para alicerçar as bases do desenvolvimento do espírito e da transformação da opinião em razão. No entendimento de Platão, a justificativa da característica física de Eros impinge a aproximação do instinto sensual com os elementos ideais. Talvez seja a ênfase que Platão atribui ao conhecimento das naturezas das entidades ideais o motivo da generalização erroneamente identificada na expressão: amor platônico. Seja como for, os caminhos e descaminhos de Eros são determinados pela maneira como se desenvolverá o processo formativo, e é nesse sentido que Eros se unifica com a Paidéia, senão vejamos.

O eros usual e corrente, o instinto irrefletido e vulgar, é vil e repudiável, porque tende à mera satisfação dos apetites sensuais; em contrapartida, o outro é de origem divina e impulsiona o zelo de servir ao verdadeiro bem e à perfeição do amado. Este segundo eros pretende ser uma força educadora, não só no sentido negativo de desviar os amantes das açốes vis [...] mas também em toda a sua essência, como força que serve ao amigo e o ajuda a expandir sua personalidade (Jaeger, 1995, p.727). 
Apraz a Eros como força educadora se aproximar da philia, ou seja, da amizade que se estabelece entre amante e amado, entre educador e educando, pois o auxílio concernente à expansão da personalidade do outro se faz numa relação amorosa que solapa, na medida do possível, os sentimentos de onipotência. A Paidéia que se engendra por meio de Eros aduz, portanto, à dimensão ética, não por acaso revigorada pelo Aristóteles da Ética a Nicômaco, sobretudo na defesa do filósofo estagirita de que a virtude moral é produto da mediania que se estabelece entre o excesso e a falta de determinado atributo. De fato, podese notar um fio condutor entre a constatação aristotélica de que se deve procurar certo equilíbrio entre a realização do desejo e as exigências sociais e a observação de Sócrates da importância de o filósofo permanecer, na busca pelo conhecimento, nem sábio de sua sabedoria e nem ignorante de sua ignorância (Platão, 1999, p.45).

A possibilidade do desequilíbrio, alertada por Aristóteles, refere-se à imposição autoritária tanto do excesso quanto da ausência de determinada característica. Assim, o ser humano que tudo teme e de tudo foge necessariamente é caracterizado como covarde, ao passo que aquele que nada teme e tudo enfrenta de forma inconsequiente torna-se temerário. A justa medida situa-se entre a ausência e o excesso da coragem. (Aristóteles, 1991, p.28). Outrossim, aquele que é consciente de que não é nem sábio de sua própria sabedoria, nem ignorante de sua ignorância não se sente seduzido pelos extremos, os quais poderiam provocar a sensação de que há um domínio completo e indelével de determinado conceito. Ele é cônscio do sortilégio ardiloso da palavra superficial, cujo domínio aparente identifica seu portador como o conhecedor de algo, como se fosse o senhor absoluto da verdade, mas que, na verdade, apenas simboliza o quão equivocada é esta pretensão que se traduz na sua soberba intelectual. Embora se sentisse tentado a exercer tal soberba em algumas ocasiões, Sócrates tinha plena consciência do poder avassalador que tal atitude portava, pois obstaculizava o desenrolar do diálogo e, portanto, do próprio processo formativo não só do educador como também do educando. Dito de outra forma, a afirmação da soberba intelectual significava a substituição implacável da ironia socrática pelo sarcasmo pedagógico. Os vários significados que o dito irônico poderia suscitar eram trocados pela única interpretação sarcástica que humilhava e destratava o interlocutor, identificando-o como o incompetente que não soubera revidar a questão feita da única forma que satisfaria o proponente de determinada questão.

Tanto na Apologia de Sócrates quanto na Ética a Nicômaco, a virtude moral é consequiência da ação do sujeito no objeto, de tal modo que também o sujeito, neste processo de interação, deve refletir sobre as consequiências de sua conduta e realizar sua autocrítica. Ora, aquele que procede dessa forma assim o faz 
porque se preocupa com o outro, ajudando-o a expandir sua personalidade. A união entre Eros e Paidéia alude à relação amorosa que se desenvolve entre os mestres e seus alunos. Se Eros corresponde ao anseio imperioso de aproximarse, de comunicar as próprias carências, facilitando, desse modo, uma identificação mimética com ou outro, essa aproximação ancora-se no aperfeiçoamento do próprio eu.

O educador que lança um olhar amoroso ao educando, no sentido anteriormente descrito, respeita a opinião do aluno que se sente encorajado a revidar o raciocínio apresentado pelo educador, o qual, ao respeitar tal revide, pode também reformular sua própria opinião. $\mathrm{O}$ aluno que se sente estimulado a devolver mais do que recebeu, pois reflete criticamente a respeito das características dos conceitos apresentados e não os toma como realidades inquestionáveis, incita também o professor a deixar de se aferrar ao modelo idealizado do mestre que não admite ser questionado, quer de forma explícita, ao chamar o aluno de incompetente, quer por meio de subterfúgios mais sutis, tal como aquele que dissimula concordar com o raciocínio do aluno e destrói, digamos assim, cirurgicamente seus argumentos. Essas atitudes do professor representam o oposto da condição de Eros como impulso cultural. Nesse sentido, ao comentar a identificação de Eros como aquilo que impulsiona o ser humano a se religar não apenas consigo mesmo, mas com o próprio sentido daquilo que é humano, Jaeger afirma o seguinte:

Para Platão, o conceito do eros torna-se assim a suma e o compêndio da aspiração humana ao bem [...] O cros, concebido como amor pelo Bem, é ao mesmo tempo o impulso para a verdadeira realização essencial da natureza humana e, portanto, um impulso cultural no mais profundo sentido da palavra [...] O eros socrático (exposto por Platão - A.Z) é o anseio de quem se sabe imperfeito por se formar espiritualmente a si próprio, com os olhos sempre fitos na Idéia. É, em rigor, o que Platão entende por "filosofia": a aspiração de conseguir modelar dentro do homem o verdadeiro Homem. (Jaeger, 1995 , p.738-740).

A religação com a dimensão do humano que Eros proporciona foi destacada não só por Jaeger como também por Giovanni Reale (2000, p.16). E esse sentido antropológico de Eros como impulso cultural reverbera, séculos depois, nas relaçóes amorosas estabelecidas entre o mestre Rousseau e seu aluno Emílio. A obra que marca o início da chamada pedagogia moderna, ou seja, o Emilio ou da educação, de Jean Jacques Rousseau, é um libelo do modo como se poderia idealizar o desenvolvimento do processo formativo do aluno, bem como a forma de atuação de Eros existente entre os agentes educacionais. 
Nesse romance de formação, sobressai-se o modo como Rousseau expressava seu afeto e também sua raiva em relação a Emílio. Esse processo formativo lembra, em alguns aspectos, as atitudes de Sócrates em relação aos seus discípulos durante o ato de ensinar. Rousseau compartilhava, de certa forma, com o procedimento irônico-pedagógico da dialética socrática, pois também o filósofo francês se recusava a fornecer repostas prontas e acabadas para os problemas enfrentados por Emílio. Há uma passagem interessante que ilustra exatamente as nuances desse método: Emílio e Rousseau perdem-se numa floresta nos arredores de Montmorency e a hora do almoço aproxima-se. É um Emílio faminto e raivoso que se desespera e, chorando, diz para Rousseau que está exausto. Rousseau responde-lhe que também se sente desta forma, mas que é preciso se orientar e pergunta-lhe as horas. Emílio responde-lhe que é meio-dia. O mestre sabe a direção da cidade, mas não responde de imediato ao aluno. Ao invés disso, incita Emílio a refletir sobre a posição da floresta em relação à cidade, de tal maneira que Emílio elabora o seguinte raciocínio: se a floresta se situava ao norte da cidade e, portanto, a cidade ao sul, e se pela sombra projetada de ambos era possível descobrir que o lado oposto corresponderia ao sul, então seria possível encontrar a cidade. Quando ambos saem da floresta e avistam Montmorency, é um eufórico Emílio que diz: "Estou vendo Montmorency! Aí na frente de nós, bem visível. Vamos almoçar, vamos depressa; a astronomia serve para alguma coisa” (Rousseau, 1992, p.194-196).

Há vários elementos relevantes nesta passagem do Emilio. Um deles referese à postura de Rousseau de assumir que também sente fome e cansaço, como qualquer outro ser humano que porventura se encontrasse em tal situação. Evidentemente, Emílio identifica-se com o preceptor e isso lhe confere certa calma que lhe permite refletir a respeito dos conhecimentos de astronomia que havia aprendido. A postura humanista de Rousseau, ao invés de distanciar ainda mais mestre e discípulo, contribuiu para o fortalecimento do respeito de Emílio em relação ao mestre. Ambos estavam, por assim dizer, no mesmo barco e cabia aos dois encontrar a saída tanto do problema quanto da floresta. As pistas fornecidas por Rousseau foram assimiladas por Emílio, de tal modo que ele devolveu, por meio da reflexão, mais do que aquilo que havia recebido.

Além disso, a alegria de Emílio foi marcante também por conta da percepção de que o conceito não é um "ser" apriorístico que surge do nada, mas é carregado de história, da história das relaçôes humanas que o compõem. O grito de que a astronomia servia para alguma coisa aludiu ao aprendizado da não-conformação com a aparente esterilidade do conceito. A Paidéia rousseauniana considerava de extrema relevância a atitude do aluno que, ao refletir sobre aquilo que aprendia, devolvia mais informaçóes do que havia recebido, pois as relacionava com a própria vida. O aprendizado da astronomia 
"saciou" a fome de Emílio. Viver não é respirar, mas sim agir. Eis a máxima pedagógica do Emilio e do ideal formativo proposto por Rousseau.

Foi nesse processo de projeção e de percepção do livro do mundo que Emílio desenvolveu as características de sua personalidade, podendo-se afirmar que ele realmente aprendeu o grande ensinamento do seu preceptor, na busca da mediania entre a vontade e as exigências sociais, a saber: as paixões jamais poderiam ser sufocadas, de tal modo que o processo formativo balizado na razão deveria aprender que "Só se tem domínio sobre as paixões pelas paixōes; é pelo domínio sobre elas que cumpre combater-lhes a tirania, e é sempre da própria natureza que é preciso tirar os instrumentos suscetíveis de regrá-la” (Rousseau, 1992, p.388).

O final comovente desse livro marca o início da maturidade de Emílio. Ele não tem vergonha de assumir sua insegurança no momento da despedida de sua condição de discípulo: "[...] enquanto eu viver precisarei de vós. Preciso mais do que nunca agora que minhas funçôes de homem se iniciam. Desempenhastes as vossas; guiai-me para que vos imite; e descansai, já está na hora de fazê-lo" (Rousseau, 1992, p.581). Emílio tem consciência da importância de Rousseau no seu processo formativo e de que tal presença, ao invés de sufocá-lo, impulsiona-o para frente, para exercer seu papel de futuro pai. A recriação do mundo, que lhe cabe, será feita também pela intervenção de Rousseau, presente na sua formação. A intervenção do mestre conserva-se modificada na reação do próprio Emílio, pois ele precisa de Rousseau e lhe confessa sua hesitação, ao dizer que necessita dele mais do que nunca, mas também reconhece que é chegada a hora de o mestre descansar, por mais difícil que the seja admitir. É nesse momento que Emílio atinge a maturidade, justamente por confessar sentir-se imaturo. O domínio racional de sua paixão é feito por meio da seiva da própria paixão. Trata-se, com efeito, de um processo formativo ideal, uma vez que a figura real de Emílio jamais existiu. Mas é exatamente esta relação entre mestre e discípulo que nos fornece elementos interessantes para o estudo dos sortilégios presentes entre professores e alunos.

São vários os professores que estimulam o aprendizado de seus alunos por meio da sedução, ainda que seja uma sedução secundária, cuja força libidinal foi obstaculizada em suas finalidades primárias - a relação sexual propriamente dita - e deslocada para fins secundários, dentre os quais se destaca o processo de ensinoaprendizagem. A presença dessa carga afetiva foi assim ilustrada por Steiner, ao referir-se à posição do aluno que expõe: "Um desejo de agradar o mestre, de atrair para si seu olhar amoroso". Tal desejo "é tão manifesto no Symposium e na Última Ceia quanto em qualquer seminário ou curso". (Steiner, 2005, p.126).

A necessidade de atrair o olhar amoroso do mestre e de receber a aprovação do raciocínio origina um prazer difícil de ser descrito, mas cuja força pode ser 
"mensurada" na situação oposta, ou seja, na ocasião em que o mesmo aluno se decepciona ao perceber que o professor não se lembra de seu nome quando the dirige a palavra. O aluno deseja diferenciar-se dos demais colegas e, em muitas ocasiōes, exige que o professor referende essa distinção diante dos demais. É nesse sentido que há um jogo "amoroso" entre os agentes educacionais. Já na perspectiva do professor, como é que alguém se sentiria ao constatar que é o centro das atenções de vários alunos?

\section{Os alunos, os professores e o sexo como vingança}

Não é tarefa fácil a de realizar a necessária autocrítica e, dessa forma, auxiliar os alunos a questionar a imagem idealizada do professor como o profissional cuja imagem corresponderá a todas as expectativas previamente construídas. A constatação, muitas vezes dolorosa, do professor de que é um ser humano, sujeito a falhas e a acertos como outro qualquer, coopera para a reflexão do aluno sobre sua aspiração de ter que se aferrar a um modelo para poder afirmar sua própria identidade. Já a possibilidade da liberdade dói, ainda que ela seja relativa e limitada a determinadas situações, tal como Sartre exemplificou magistralmente em seus escritos de filosofia e em seus romances.

O jogo que se estabelece entre professores e alunos durante o processo de ensino-aprendizagem é notadamente caracterizado não só pelos elementos objetivos relativos aos conteúdos das disciplinas, como também por componentes subjetivos que alicerçam as ambíguas relaçōes entre ambos. Na verdade, é equivocada a crença de que a relação de ensino-aprendizagem só comporta a discussão dos conteúdos objetivos. Para lembrar Aristóteles, é evidente que a elaboração desmedida dos sentimentos ambíguos de amor e ódio entre os agentes educacionais se torna perniciosa. Isto ocorre quando o professor que não domina os conteúdos de sua disciplina e, praticamente, limita suas "aulas" à exposição de seus problemas pessoais, justifica tal atitude através do desejo de "aproximar-se" mais dos alunos. Por outro lado, é também falso o outro excesso, ou seja, a negação desses sentimentos ambíguos, uma vez que prevalece a explicação do professor de não ser de sua competência - e essa é mesmo uma palavra adequada - ouvir os sentimentos dos alunos sobre o domínio de seus conhecimentos e, principalmente, de sua didática.

Para Adorno, aqueles que se preocupam com o desenrolar do processo de ensino-aprendizagem precisam recordar um imperativo categórico que não é estranho à filosofia, a saber: a repressão da angústia e/ou do medo possibilita condiçôes propícias para que o ódio prolifere e se dissemine (Adorno, 1971, p.97). Daí a importância da não-repressão da angústia e/ou do medo. Ora, isto também se aplica aos professores e aos alunos, sobretudo pelo fato de que 
as frustraçōes destes últimos não deixam de existir quando são impedidas de se manifestar nas salas de aula. Elas encontram canais de expressão das mais variadas formas. Seguindo essa linha de raciocínio, o trote universitário pode ser identificado como uma espécie de vendeta dos veteranos em relação às humilhações e violências simbólicas que sofreram, em silêncio, de seus professores e que são descontadas em seus calouros. É interessante observar o modo como os veteranos expressam o quanto odeiam seus professores no transcorrer da aulatrote, quando mimetizam os comportamentos que recriminam de seus mestres, tais como a intransigência e a falta de diálogo, e os representam caricaturalmente, na condição de "professor", diante dos atônitos calouros (Zuin, 2002, p.91).

A história da formação de representações aversivas dos alunos em relação aos professores acompanha a profissão de ensinar desde os seus primórdios. Já na Grécia antiga, na Atenas do quinto século antes de Cristo, o aluno era educado por um escravo que fora vencido no campo de batalha e que era mantido nessa condição pelo emprego da coerção física, ou seja, o chamado paidagogos (Cambi, 1999, p.84; Manacorda, 1989, p.48). A desvalorização do intelecto em relação ao emprego da força física é notada também por Adorno quando ele lembra o descaso do guerreiro em relação ao professor, ou seja, àquele capaz de entender as coisas do espírito:

O menosprezo ao professor - pelo menos na Alemanha, talvez nos países anglo-saxóes e com certeza na Inglaterra - pode ser caracterizado como ressentimento do guerreiro, que por um permanente mecanismo de identificação acaba por impregnar o povo como um todo. (Adorno, 2000, p.162).

A depreciação da figura do professor também se nutre do anseio de dominar a esfera do espírito, ou seja, uma esfera alusiva à profissão de ensinar. Se, historicamente, os alunos foram "educados" para reprimir a angústia e/ou o medo engendrados nas relaçóes com seus mestres, o que aconteceria se eles encontrassem um meio para expor não só suas insatisfações como também o desejo de se aproximar do professor, de tal modo que dificilmente pudessem ser alvo de retaliação dos professores? A meu ver, o sítio de relacionamentos virtuais chamado Orkut funciona, atualmente, como um meio também para os alunos que desejam expressar aquilo que verdadeiramente pensam de seus mestres. Criado em 22 de janeiro de 2004 pelo projetista-chefe e engenheiro do Google chamado Orkut Büyuikkokten, o Orkut é um sítio de relacionamentos on line que "permite que o internauta tenha sempre, a um clique do mouse, uma lista de amigos chegados e comunidades com perfis semelhantes" (2004). Cada um dos membros do Orkut possui uma conta e um perfil que 
comunica aos outros internautas características de personalidade, tais como hábitos de leitura, gostos musicais e culinários, por exemplo. Caso algum internauta se identifique com as preferências de determinado usuário, ambos podem se incluir como "amigos" em suas respectivas contas, de tal maneira que, gradativamente, são formadas as comunidades virtuais, cujos tópicos amealham os mais variados assuntos.

Dentre as centenas de comunidades sobre o tema professor, destacam-se aquelas cujos participantes se referem aos professores com uma conotação sexual, tanto no sentido da repulsa quanto no da aproximação. Eis algumas das comunidades mais significativas: Eu tenho um professor F.D.P. São milhares os inscritos nessa comunidade. No seu portal de entrada, há a seguinte mensagem: "Quem não tem ou não teve um professor filho da puta? Daquele de falsa amizade, que sempre ferra na prova, não deixa colar, faz num sei quantos tipos de prova, terrorista e tal? Pois é, há muitos desses por aí, querendo cada vez mais botar no seu c...Mostre sua indignação e revolta entrando pra nossa comunidade!"

Já em outra comunidade, com título praticamente idêntico ao anterior: $E u$ tenholtive um professor F.D.P, observam-se os seguintes dizeres: "Você tem um professor que pega no seu pé? Você sofre com um professor que não sabe a matéria e bota a prova fudendo? Você tem um professor burro que se acha "o bonzão"? Em suma, você tem um professor filho da puta? Se você respondeu sim a pelo menos uma dessas perguntas, esta é a sua comunidade!!!”. Ex-alunos também formaram uma comunidade com os seguintes títulos e protestos: Eu já tive um professor FD.P. Essa comunidade é pra aqueles ke já tiveram um ou mais professores filhas da puta....aquele que da risada quando passa a nota das provas ou ki axa super divertido quando dexa alguém di exame". Em outra comunidade, a repulsa dos alunos com relação a seus mestres é exposta da seguinte forma: Odeio professor Filho da Puta. Se você tem ou já teve um professor filho da puta essa é a sua comunidade! Entre e meta o pau nesses sacanas, que se acham cheios de merda e só pensam em fuder a galera!"

Num primeiro momento, é estarrecedor deparar-se com a quantidade de xingamentos em relação ao professor. Mas não foi anteriormente asseverado que as representações aversivas dos alunos em relação a seus mestres acompanham tal profissão desde os seus tempos primevos? Qual seria a "novidade" das queixas expostas nas comunidades do Orkut? Ora, não se pode desconsiderar o fato de que a maioria de tais comunidades que achincalham os mestres é composta por títulos e comentários de conotação sexual. A “infração" dos alunos em relação às normas tacitamente acordadas com seus mestres de que não poderiam expressar publicamente tais sentimentos remete à análise das ponderações freudianas sobre a dinâmica psicossocial dos tabus. Ao refletir sobre a 
persistência dos tabus nas tribos primitivas, o fundador da psicanálise afirma o seguinte:

Mas uma coisa certamente decorreria da persistência do tabu, a saber, que o desejo original de fazer a coisa proibida deve persistir ainda entre as tribos em causa. Elas devem, portanto, ter uma atitude ambivalente para com os seus tabus. Em seu consciente não existe nada mais que gostassem de fazê-lo do que violá-los, mas temem fazê-lo; temem precisamente porque gostariam, e o medo é mais forte que o desejo [...] A base do tabué uma ação proibida, para cuja realização existe forte inclinação do inconsciente. (Freud, 1999, p.41).

Embora anseiem violar o tabu que representa exatamente aquilo que mais desejam, os membros dos coletivos de tais tribos receavam fazê-lo em decorrência do pavor da possível retaliação dos deuses. Porém, será que este mesmo raciocínio se aplica no caso dos alunos que descarregam odiosamente a angústia e/ou o medo reprimido através de suas participaçóes nas comunidades virtuais? O desejo da violação do tabu pode ser observado tanto nos membros das tribos primitivas quanto nos alunos, mas a psique de ambos difere pelo fato de que os alunos aparentemente não temem expor publicamente a ambigüidade do desejo. Por maior que seja a preocupação da garantia de anonimato das identidades dos usuários do Orkut, uma vez que o próprio internauta pode utilizar um pseudônimo em seus comentários, não há, na internet, código algum que seja completamente indecifrável códigos que sejam completamente indecifráveis. Por mais que o participante da comunidade virtual dificulte a descoberta de sua identidade, os vestígios de seus endereços eletrônicos podem ser rastreados. E se sua identidade pode ser revelada, como explicar que o desejo de expor aquilo que intimamente pensa do professor seja mais poderoso que o medo da possível retaliação? Não há uma única resposta para esta pergunta. É possível respondê-la da seguinte forma: os comentários que aviltam os professores são, na sua maioria, gerais, pois não se referem a um professor que leciona numa determinada instituição escolar, o que facilitaria a coragem de o aluno expor o ódio, mesmo podendo ser identificado. Mas há também o seguinte esclarecimento: a exposição pública do ódio é mais potente do que o medo da vingança, porque tal aversão é uma formação reativa do desejo de aproximação não mais oculto.

O ódio em relação ao professor é acompanhado de uma conotação sexual que lembra as palavras de Freud (2004, p.105) de que quaisquer processos afetivos mais intensos que ultrapassassem certo limite, tais como as excitações assustadoras e angustiantes, seriam propagados para a sexualidade, ou seja, teriam um efeito sexualmente excitante. Para o psicanalista, isso explicaria o 
fato de muitas pessoas sentirem prazer no contato com situaçôes que produzem afetos aparentemente desprazerosos, tais como angústia, medo ou horror, desde que houvesse algum tipo de circunstancia secundária que atenuasse um pouco a gravidade dessa sensação. A "distância" virtual estabelecida pela internet arrefece a intensidade das sensações de angústia e de medo, ao mesmo tempo que facilita a exposição do sadismo que, de acordo com Freud, é um dos componentes da pulsão sexual. Assim, torna-se excitante admoestar o professor porque ele é também objeto de desejo do aluno.

Em algumas situações, a exposição desse desejo torna-se explícita, tal como pode ser observado nos títulos das seguintes comunidades virtuais: Eu tenho um professor gato; Meu professor é muito gostoso; Eu já beijei um professor, i dai?; Eu peguei meu professor; Sou apaixonada por um professor; Eu amo meu professor; Eu já fiquei com um professor. Não é fortuita a auto-exaltação dos alunos que se relacionaram sexualmente com seus professores, pois romperam a barreira do hiato intelectual e provaram para si e para seus colegas que seus mestres são também seres humanos. É como se os alunos se vangloriassem de terem violado o tabu do professor rotulado como ser inatingível, por meio da intimidade física, de uma afinidade eletiva corpórea. Neste caso, o desejo de contato físico não é auto-suficiente, mas fornece o alento para a aspiração do aluno de aproximar-se daquele que se afasta intelectualmente. Esse querer estar próximo também pode ser notado nos títulos das comunidades: Eu já bebi com meu professor; Meu professor fuma maconha; Meu professor fala errado; c Meu professor se parece com....

A investigação dos comentários dos participantes de tais comunidades possibilita engendrar outra interessante comparação com as consideraçôes de Freud sobre as características dos tabus. Quando pondera a respeito das proibiçôes que deveriam ser obedecidas pelos membros das tribos no cumprimento das leis dos tabus, Freud observa que:

Por detrás de todas essas proibições parece haver algo como uma teoria de que elas são necessárias porque certas pessoas e coisas estão carregadas de um poder perigoso que pode ser transferido através do contato com elas, quase uma infecção [...] o fato mais estranho parece ser que qualquer um que tenha transgredido uma dessas proibiçóes adquire, ele mesmo, a característica de ser proibido - como se toda carga perigosa tivesse sido transferida para ele. (Freud, 1999, p.31).

A força dessa carga perigosa é tamanha que muitos daqueles que transgrediam determinado tabu caíam em depressão e até mesmo morriam, completamente proscritos pelos outros membros da tribo. Era o chamado castigo dos deuses. Mas e no caso dos alunos "transgressores" que confessam publicamente 
o desejo pelo professor e que não têm receio de assumir que tiveram relações sexuais com os mestres? Que tipo de carga é transferida para o aluno que solapa as leis dos tabus sexuais?

O poder de que se assenhoreiam é o de ter "dominado" a esfera do espírito, representada pelo professor, por meio daquilo que o próprio espírito historicamente desprezou ou procurou controlar: o prazer sexual. Se o olhar amoroso do professor não pode ser retribuído na sala de aula, será por meio do sexo que a vingança se afirmará. É como se eles estivessem sadicamente provocando seus mestres. E por falar em mestres, uma das mais famosas provocaçōes de Zaratustra aos seus discípulos é a seguinte: "Quem de vós pode, ao mesmo tempo, rir e sentir-se elevado? (Nietzsche, 2005, p. 66). Os alunos de tais comunidades virtuais poderiam lhe responder: "Nós podemos, pois superamos nossos deuses e os derrubamos de seus pedestais. Eles são pessoas de carne e osso, por mais que tentem afirmar o contrário!". Os alunos ufanam-se de poder rir e elevar-se ao mesmo tempo, proclamando assim uma nova forma de transgressão do tabu, pois a violação do ato proibido não se restringe mais ao âmbito físico da escola, mas, sim, espraia-se por meio da rede mundial de computadores.

\section{Conclusão}

Essa provocação dos alunos encontra afago na sociedade da indústria cultural hodierna, sobretudo pelo fato de que atualmente, por ser o sexo mercantilizado em todas as esferas do mundo da vida, há uma necessidade cada vez maior de que os estímulos que alimentam o prazer - que nunca se realiza por completo — sejam cada vez mais recrudescidos. Já não se "sente" mais tanto prazer quando se contempla o sexo representado nos filmes, pois ele tem que ser feito e observado ao vivo por meio do voyeurismo que domina os programas de televisão, tais como o Big Brother Brasil, da rede Globo de televisão.

O fenômeno da dessexualização do próprio sexo (Adorno, 1996, p. 535), ou seja, do sexo que não se realiza, apesar de o estágio preliminar do prazer ser inflacionado ao extremo através dos choques audiovisuais de tais programas, é "compensado", no caso dos alunos que proclamam sua vitória sexual em relação ao professor, pelo acirramento das tendências sadomasoquistas da pulsão sexual. Evidentemente, a presença de tais tendências, embora seja hegemônica, não é exclusiva, haja vista não se poder negar a carga afetiva da sedução secundária existente entre os professores e alunos, que pode se tornar predominante em alguns casos. Mas há uma diferença qualitativa entre o espírito de um tempo que incentiva a metamorfose de Eros no impulso cultural, ao reforçar o anseio do olhar amoroso do mestre que dialoga com os educandos, e a cultura cujo processo de industrialização é simpático ao desafio do aluno que, no Orkut, 
vinga-se sadicamente de sua anterior submissão masoquista: Eu já beijei um professor, i dai?

$\mathrm{O}$ antiplatonismo que atualmente viceja na internet é revelador de uma aporia aparentemente imperceptível, pois tanto no destrato sexual que foi exposto nas comunidades virtuais dos alunos, cujos professores são, a seu ver, "filhos da puta", quanto nos títulos das comunidades dos educandos que afirmaram ter tido algum contato sexual com seus mestres observa-se o desejo de aproximação. E esse anseio desvela a distância, que é muito maior daquela que separou Apolo e Dafne, entre os alunos e o professor. O mesmo professor que, em muitas ocasióes, gaba-se de sua soberba intelectual e humilha sarcasticamente os educandos, desestimulando-os a desenvolver seu próprio raciocínio. A ausência de respeito é proporcional à afirmação do sentimento de onipotência do mestre que é muito bem percebido e assimilado por seus alunos. Tornase cada vez mais rara a possibilidade de o professor refletir sobre o significado de uma frase como esta: "É preciso começar por deixar de ser professor para poder sê-lo" (Vernant, 2002, p.32). Ou seja, sem o necessário momento da autocrítica, o mestre procura aferrar-se à ilusão de eternidade de sua condição de autoridade, sem perceber que, gradativamente, ela se transforma em autoritarismo. Definitivamente, os alunos não mais se aquietam diante de tal quadro. Eles rompem as amarras tácitas dos tabus sexuais em relação a seus mestres e expressam publicamente, por meio de sua revolta e em tempo on line, uma espécie de futuro do pretérito, ou seja, aquilo que poderia ter ocorrido e que permanece ainda na condição de promessa: uma aproximação amorosamente respeitosa com seus professores, na tentativa de estabelecer, algum dia, o reconhecimento geral de que o jogo pedagógico não foi em vão.

\section{Referências bibliográficas}

ADORNO, Theodor W. Erziehung nach Auschwitz. In: Erziehung zur Mündigkeit. Frankfurt am Main: Suhrkamp Verlag, 1971, 147 p.

ADORNO, Theodor W. Gesammelte Scriften 10.2. Frankfurt am Main: Suhrkamp Verlag, $1996,843 \mathrm{p}$.

ADORNO, Theodor W. Tabus a respeito do professor. Tradução de Newton Ramos de Oliveira. In: ZUIN, Antonio; PUCCI, Bruno; RAMOS-DE-OLIVEIRA, Newton. Adomo: o poder educativo do pensamento critico. 3.ed. Petrópolis: Vozes, 2000, $191 \mathrm{p}$.

ARISTÓTELES. Ética a Nicômaco. Tradução de Leonel Vallandro e Gerd Bornheim. São Paulo: Abril Cultural, 1991, 283 p.

CAMBI, Franco. História da Pedagogia. Tradução de Alvaro Lorencini. São Paulo: Editora da Unesp, 1999, 701 p. 
COLIVA, Anna. Apollo e Dafne. Milano: Tascabili degli Editori Associati, 1998, 84 p.

FREUD, Sigmund. Totem e tabu. Tradução de Orizon Carneiro Muniz. Rio de Janeiro: Imago, $1999,164 \mathrm{p}$.

FREUD, Sigmund. Drei Abhandlungen zur Sexualtheorie. Frankfurt am Main: Fischer Verlag, 2004. $151 \mathrm{p}$.

JAEGER, Werner. Paidéia: a formação do homem grego. Tradução de Artur Parreira. São Paulo: Martins Fontes, 1995, 1413 p.

MANACORDA, Mario A. História da Educação: da antiguidade aos nossos dias. Tradução de Gactano Lo Mônaco. São Paulo: Cortez e Autores Associados, 1989, 382 p.

NIETZSCHE, Friedrich. Assim falou Zaratustra. Tradução de Mário da Silva. Rio de Janeiro: Civilização Brasileira, 2005, $381 \mathrm{p}$.

PLATÃO. Diálogos - O Banquete, Fédon, Sofista, Politico. Tradução de José Cavalcante de Souza, Jorge Paleikat e João Cruz Costa. São Paulo: Abril Cultural, 1991, 264 p.

PLATÃO. Apologia de Sócrates. Tradução de Maria Lacerda de Moura. Rio de Janeiro: Ediouro, $1999,138 \mathrm{p}$.

REALE, Giovanni. Introduzione. In: Platone-Simpósio. Milano: Bompiani, 2000, 210 p.

ROUSSEAU, Jean Jacques, Emilio ou da educação. Tradução de Sérgio Milliet. Rio de Janeiro: Bertrand Brasil, 1992, 581 p.

STEINER, George. Liçôes dos mestres. Tradução de Maria Alice Máximo. Rio de Janeiro: Record, 2005, $239 \mathrm{p}$.

VERNANT, Jean Pierre. Entre mito e politica. Tradução de Cristina Murachco. São Paulo: Edusp, 2002, 517 p.

ZUIN, Antônio A. S. O trote na universidade: passagens de um rito de iniciação. São Paulo: Cortez, 2002, $120 \mathrm{p}$.

\section{Artigos disponíveis na internet}

1) http://www.folha.uol.com.br/informatica/ult124u16038.shtml Orkuté a mais nova febre da rede a pegarno Brasil, 2004,2p.

2) http://www.igutenberg.org/esbase.html. O uiltimo dia da Escola Base, 2007, 1 p.

Recebido em 22 de março de 2007 e aprovado em 23 de novembro de 2007. 